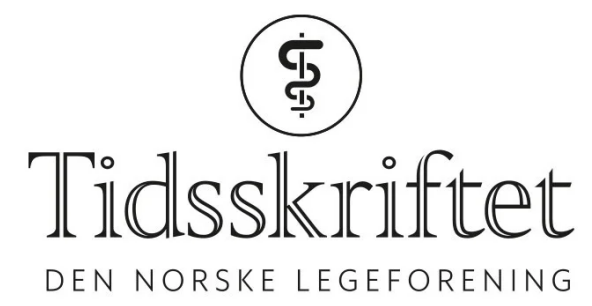

\title{
Selvpåført arsenikkforgiftning
}

TIDLIGERE I TIDSSKRIFTET

JULIE DIDRIKSEN

julie.didriksen@tidsskriftet.no

Tidsskriftet

I Tidsskriftets utgave 3/1915 kunne vi lese en kasuistikk om en mann som hadde inntatt arsenikk etter at han ble innkalt til militærtjeneste (Tidsskr Nor Lægeforen 1915; 35:105-6).

Akut arsenikforgiftning

AV M. REEHORST 


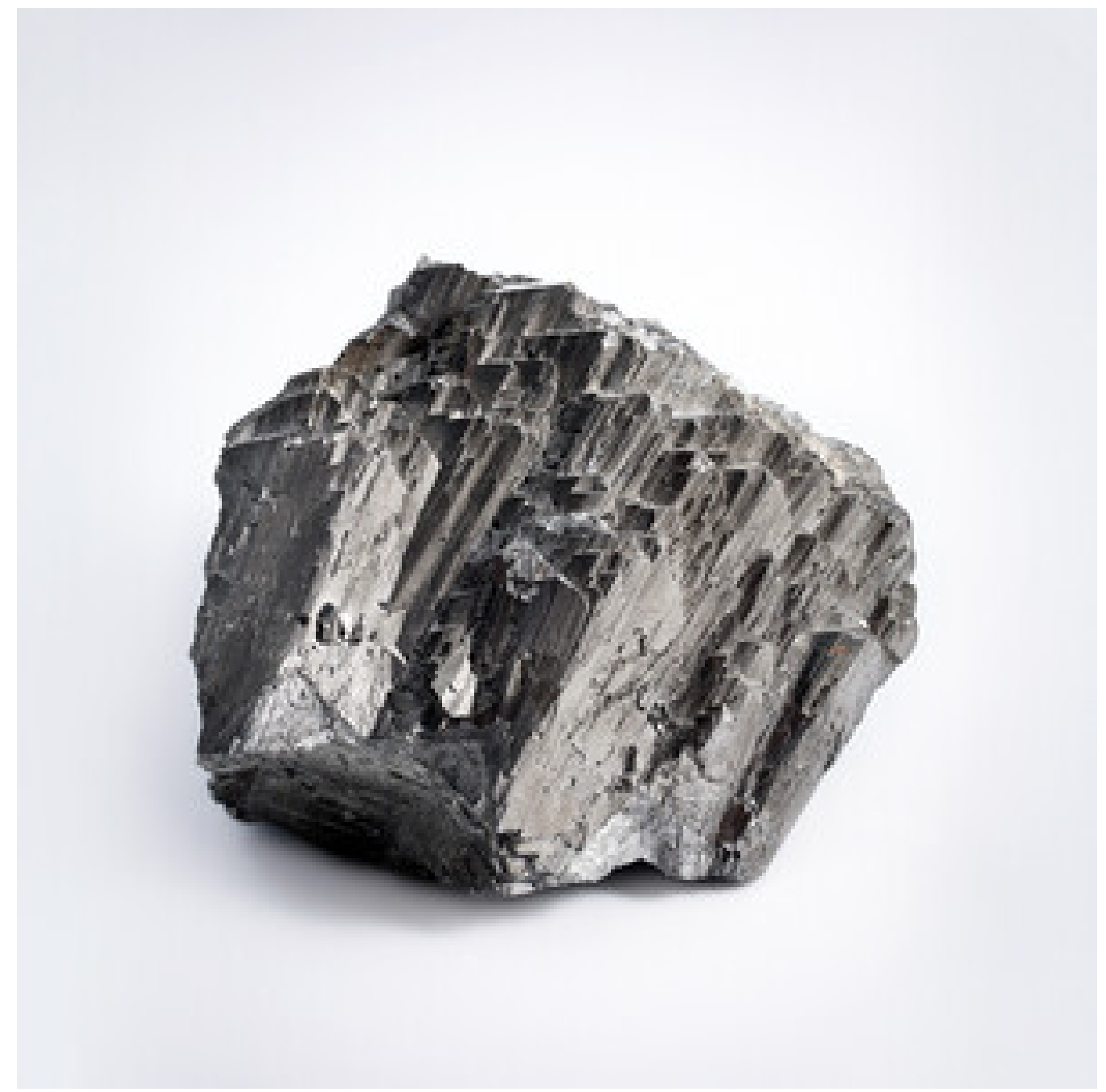

Illustrasjon: AndreasKermann/iStock

Den 4de september 1914 om eftermiddagen ved 6-tiden blev jeg hentet i sykebes $ø \mathrm{k}$ til en mand, som bodde omtrent $20 \mathrm{~km}$. fra min bopæl, og som sagdes at lide av sterke mavesmerter forbundet med brækninger. Kommen frem fik jeg vite at vedkommende samme dags morgen ved $1 / 28$-tiden hadde drukket omtrent en teske av Sol. arsenical. concentrat. Medicinen hadde han faat av dyrlæge for et aar siden til kreaturvask. Flasken var behørig signert med giftmerke og bruksanvisning; dessuten medfulgte en trykt veiledning. - Vedkommende hadde i længere tid været i noget deprimert sindsstemning, som yderligere forværredes ved hans indkaldelse til nøitralitetsvernet. Samme dags morgen han skulde avsted, gik han ned i kjelderen, hvor han hadde gjemt medicinen, hældte litt av flasken i en kop med vand og drak. Han satte sig i karjolen for at kjøre ned til dampskibet. Kommen avsted ca. $1 \mathrm{~km}$. maatte han vende paa grund av sterke mavesmerter forbundet med brækning. I dagens løp hadde han drukket adskillig melk, som han kastet op. Ved min ankomst var han somnolent med daarlig puls, kastet sig urolig frem og tilbake i sengen, ansigtet infaldent med dyptliggende øine, klaget over brænden i svelget, tørst og sterke smerter i epigastriet. Forlangte stadig drikke, kastet op, brækningene indeholdt litt blod. Skjønt jeg ansaa en maveutskylling efter saa lang tids forløp for uvirksom, foretok jeg den dog. Efterpaa forordnedes antidotum arsenici. Den følgende dag fik jeg besked om, at han var meget bedre og at omgivelserne hadde haap om, at han skulde komme sig; han hadde havt diarré, men slet ikke koleralignende uttømmelser, samt nsus.

«Medicinen hadde han faat av dyrlege for et aar siden til kreaturvask» 
Den 6 te september blev jeg paany hentet. Tilstanden hadde forværret sig. Han var nu blit mere urolig, ængstelig, klaget over sterke svelgningssmerter samt smerter i læg og laar, hvor der saaes smaa peterchier. Blæren dom. Han hadde efter sigende omtrent ikke latt vandet siden han blev syk. Han døde samme dags aften kl. 11/2/2.

Gaar man ut fra, at han har tat en deske av sol. arsenical. concentrat., har arsenikdosen været adskilig over 1 gr. Den letale arsenikdose begynder efter prof. Poulsson med o,10 gr. At pasienten levet over $2^{1 / 2} \mathrm{~d} \emptyset g n$ kan alene forklares derved, at han har har brækket op størsteparten av den indatgne dose.

Til slut skal oplyses at vedkommende gav mig den besked, at det ikke var hans mening og ta livet av sig; han vilde bare gjøre sig syk for at slippe militærtjenesten.

Publisert: 4. november 2021. Tidsskr Nor Legeforen. DOI: 10.4045/tidsskr.21.0462

(C) Tidsskrift for Den norske legeforening 2023. Lastet ned fra tidsskriftet.no 26. april 2023. 